\title{
NEMATOSIT DAN TIGA MACAM WARNA KARANG Galaxea fascicularis (Linnaeus) DITEMUKAN DI TERUMBU KARANG PANTAI MALALAYANG KOTA MANADO
}

\section{(Nematocyts and Three Color Morphs of Galaxea fascicularis (Linnaeus) Found in the Reef of Malalayang Shore in Manado City)}

\section{Carolus P. Paruntu}

Program Studi Ilmu Kelautan, Fakultas Perikanan dan Ilmu Kelautan, Universitas Sam Ratulangi, Manado

e-mail : carolusparuntu@yahoo.com

\begin{abstract}
Nematocyts and three color morphs of Galaxea fascicularis (Gs, B dan Wt) found abundant in the reef around old Nusantara Diving Center (NDC) in the Malalayang shore, town of Manado, North Sulawesi Province. They were being studied and analyzed in the Marine Biological Laboratory, Faculty of Fisheries and Marine Science, Sam Ratulangi University. Three of the 25 major types nematocysts known belong to phylum Cnidaria, were observed in three color morphs of G. fascicularis, i.e. MpM, MbM and HI. MpMs were found abundant in the tip of the ordinary tentacles of three color morphs of this species. MpM from Wt coral color morph had smaller nematocyst capsule and shorter shaft than those from Gs or $B$ coral color morphs, while MpM capsule and shaft from $G$ s and $B$ were similar. The present study shows that nematocyst type and body characteristics from three color morphs of $G$. fascicularis are different between Gs or $B$ with $W t$ coral color morphs, while those from $G s$ and $B$ are similar. It is suggested that three color morphs of $G$. fascicularis are different species based on nematocyst morphology and its body characteristics. The future studies about nematocyst dimension and composition, DNA and the environmental factors of habitat on the color morphs of $G$. fascicularis are needed for deciding whether they are similar or belong different species.
\end{abstract}

Keywords: Nematocysts, color morph, G. fascicularis, reef, Malalayang shore, Manado city

Nematosit dan tiga macam warna karang $G$. fascicularis (Gs, B dan Wt) ditemukan berlimpah di terumbu karang sekitar Nusantara Diving Center (NDC) lama di pantai Malalayang Kota Manado Provinsi Sulawesi Utara, diteliti di Laboratorium Biologi Kelautan, Fakultas Perikanan dan IImu Kelautan Universitas Sam Ratulangi. Tiga dari 25 nematosit yang dikenal dalam filum Cnidaria, diamati dalam tiga macam warna karang G. fascicularis, yaitu MpM, MbM dan HI. Tipe MpM ditemukan paling dominan terdapat dalam bagian ujung tentakel normal dari tiga macam warna karang spesies ini. MpM dari warna karang Wt memiliki bentuk kapsul nematosit yang lebih kecil dan tangkai-tangkai lebih pendek dibandingkan dengan yang ada pada warna karang $G$ s atau $B$, sedangkan yang dari $G$ s dan $B$ adalah mirip. Penelitian sekarang ini memperlihatkan bahwa tipe nematosit dan karakteristik tubuh dari tiga macam warna karang $G$. fascicularis adalah berbeda antara $G$ s atau $B$ dengan $W t$, sedangkan yang dari $G$ s dan $B$ adalah mirip. Penelitian sekarang ini mengusulkan bahwa ketiga macam warna karang $G$. fascicuaris ( $G$ s atau $B$ dengan $W t$ ) adalah spesies yang berbeda berdasarkan morfologi nematosit dan karakteristik tubuhnya. Penelitian selanjutnya tentang dimensi dan komposisi nematosit, DNA dan pengaruh faktor lingkungan habitat terhadap bermacam warna karang G. fascicularis adalah penting untuk memastikan apakah mereka spesies yang sama atau berbeda.

Kata kunci: Nematosit, macam warna, G. fascicularis, terumbu karang, pantai Malalayang, Kota Manado 


\section{PENDAHULUAN}

Paruntu \& Souw (2014) telah meneliti morfologi nematosit dari dua spesies karang Scleractinia, yaitu Seriatopora hystrix dan Seriatopora caliendrum dari terumbu karang pantai Malalayang Kota Manado, dan mengusulkan bahwa kedua spesies adalah spesies yang serupa berdasarkan morfologi nematosit, dan itu didukung oleh pernyataan Veron (1986) bahwa mereka adalah dua spesies yang serupa. Beberapa macam warna karang Galaxea fascicularis (Linnaeus) yang ditemukan di perairan Okinawa Jepang sudah digambarkan dan berbagai aspek interaksi antara perbedaan warna karang tersebut sudah dipelajari (Hidaka \& Yamazato, 1984; Hidaka \& Yamazato, 1985; Hidaka \& Miyazaki, 1984). Kemungkinan perbedaan dalam morfologi skeleton, tipe nematosit, tingkah laku, dan reproduksi antara beberapa macam warna karang tersebut sudah diinvestigasi dalam kondisi laboratorium (Hidaka \& Yamazato, 1985; Hidaka, 1992). Karakteristik dari berbagai macam warna karang $G$. fascicularis di Indonesia, khususnya di perairan Kota Manado Provinsi Sulawesi Utara belum pernah dilakukan penelitian. Tujuan penelitian ini adalah untuk mengetahui dan menggambarkan tipe nematosit dan karakteristik dari tiga macam warna karang $G$. fascicularis (GS, B dan Wt) yang ditemukan berlimpah di terumbu karang sekitar NDC lama pantai Malalayang Kota Manado.

\section{METODE PENELITIAN}

Koloni-koloni dari tiga macam warna karang $G$. fascicularis yang dominan dikumpulkan dari terumbu karang sekitar NDC lama di pantai Malalayang Kota Manado. Setiap macam warna karang tersebut diambil 3 koloni yang akan diuji. Pengambilan koloni-koloni tersebut dilakukan pada kedalaman 2 - 5 meter dengan menggunakan peralatan selam (SCUBA) dan pahat. Selanjutnya koloni-koloni tersebut diletakkan pada wadah ember yang telah disiapkan dengan memisahkan setiap koloni berdasarkan warna karang. Setiap warna karang diawetkan dengan $10 \%$ formalin dalam air laut. Disamping itu dikumpulkan koloni-koloni hidup dari masing-masing warna karang untuk keperluan identifikasi dan pembuatan foto.

Hewan uji yang telah dikumpulkan dalam keadaan hidup dibawa ke Laboratorium Biologi Kelautan Fakultas Perikanan dan IImu Kelautan UNSRAT untuk keperluan identifikasi secara visual. Untuk memudahkan proses identifikasi digunakan mikroskop yang berkamera Nikon dengan pembesaran 2X lensa objektif dan diambil beberapa gambar foto. Disamping itu juga, untuk melengkapi proses identifikasi, kolonikoloni dari tiga macam warna karang $G$. fascicularis ditempatkan dalam akuarium kaca yang berisi air laut dan diambil beberapa foto dengan menggunakan kamera Nikon, lensa mikro nikkor $55 \mathrm{~m}$. Penentuan perbedaan warna karang $G$. fascicularis didasarkan pada karya ilmiah dari Hidaka \& Yamazato (1985), yang menerangkan bahwa Gs adalah warna polip coklat tetapi tentakel-tentakel di atas septa utama berwarna hijau, coenesteum lunak dan pergerakan tentakel tidak aktif; $W$ t adalah warna polip coklat tetapi tentakel-tentakel lateral berwarna putih atau hijau fluorescent, coenosteum keras dan pergerakan tentakel aktif; dan $B$ adalah warna polip keseluruhan coklat muda, coenosteum lunak dan pergerakan tentakel tidak aktif.

Jaringan tentakel normal bagian ujung diambil dari polip-polip karang yang telah diawetkan dengan menggunakan pinset atau pipet, kemudian itu diletakkan di atas slide glass, dan ditutup dengan cover glass, 
dilumatkan secukupnya dan diletakkan di bawah mikroskop untuk diamati dan diuji nematositnya. Foto-foto nematosit diambil di bawah mikroskop (Lobophot2) yang berkamera Nikon dengan pembesaran $100 \mathrm{X}$ lensa objektif untuk pengambilan gambar closeup dengan tujuan identifikasi dan dokumentasi nematosit.

\section{HASIL DAN PEMBAHASAN}

Ada tiga macam warna karang G. fascicularis yang paling dominan ditemukan di teruimbu karang sekitar NDC Iama pantai Malalayang Kota Manado (Tabel 1).

Bagian ujung tentakel normal lateral dari tiga macam warna karang G. fascicularis memiliki tipe nematosit microbasic p-mastigophore (MpM), microbasic b-mastigophore (MbM), dan holotrichous isorhizas $(\mathrm{HI})$, dan Spirosit (bukan nematosit). Tipe nematosit MpM dan MbM berbentuk seperti obat kapsul. Di dalam kapsul MpM dan MbM

Tabel 1. Warna dan pergerakan tentakel dari tiga macam warna karang G. fascicularis yang paling dominan ditemukan di terumbu karang sekitar NDC lama pantai Malayang Kota Manado

\begin{tabular}{|c|c|l|c|}
\hline No & Simbol & $\begin{array}{l}\text { Warna Polip } \\
\text { Karang }\end{array}$ & $\begin{array}{c}\text { Pergerakan } \\
\text { Tentakel }\end{array}$ \\
\hline 1 & Gs & $\begin{array}{l}\text { Coklat tetapi } \\
\text { tentakel di } \\
\text { atas septa } \\
\text { utama } \\
\text { berwarna } \\
\text { hijau dan aktif } \\
\text { tentakel } \\
\text { lateral warna } \\
\text { putih }\end{array}$ & Tan \\
\hline 2 & $B$ & $\begin{array}{l}\text { Keseluruhan } \\
\text { coklat }\end{array}$ & Tidak aktif \\
\hline 3 & $W t$ & $\begin{array}{l}\text { Coklat tetapi } \\
\text { tentakel } \\
\text { lateral } \\
\text { berwarna } \\
\text { hijau } \\
\text { fluorescent }\end{array}$ & Aktif \\
\hline
\end{tabular}

Keterangan: $\mathrm{Gs}=$ Green Septa; $W t=$ White tentacles; $B=$ Brown.

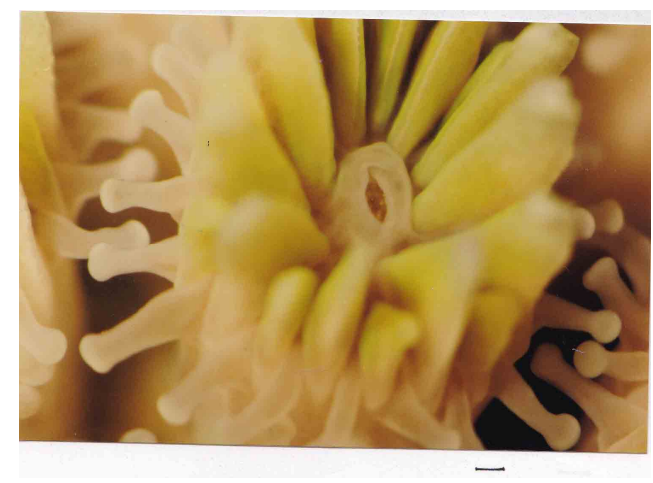

Gambar 1. Polip karang G. fascicularis (Gs). Skala bar $=100 \mu \mathrm{m}$.

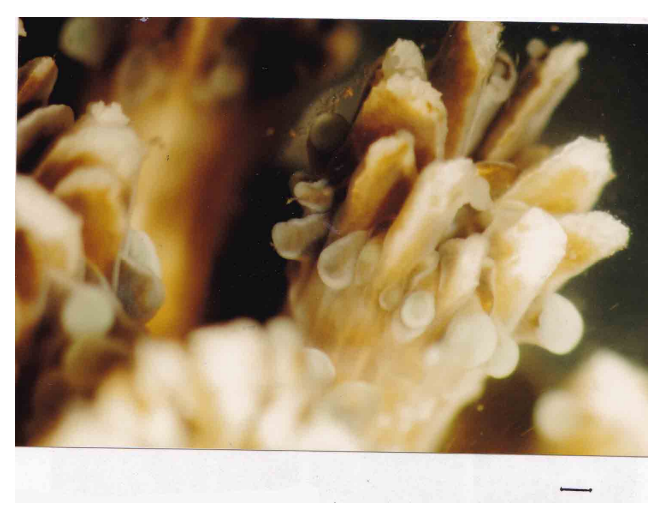

Gambar 2. Polip karang G. fascicularis (B). Skala bar $=100 \mu \mathrm{m}$.

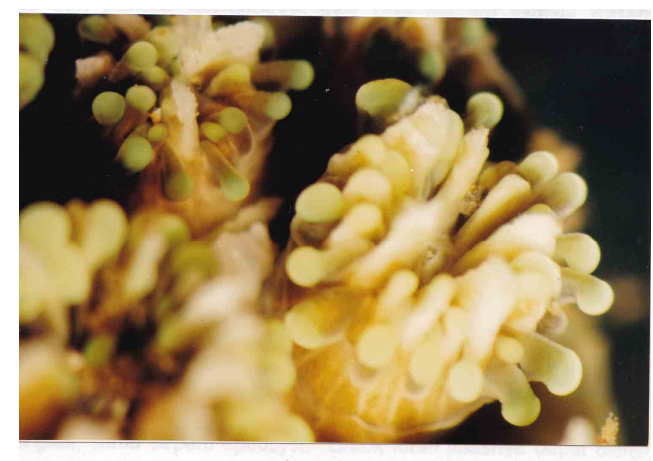

Gambar 3. Polip karang G. $\overline{\text { fascicularis }}$ $(W t)$. Skala bar $=100 \mu \mathrm{m}$.

terlihat adanya tangkai dan benang bergulung - gulung. Ujung tangkai nematosit MpM yang dalam keadaan belum melepaskan tangkai ke luar dari kapsulnya, berbentuk seperti huruf "V". Tipe nematosit HI tidak memiliki tangkai 


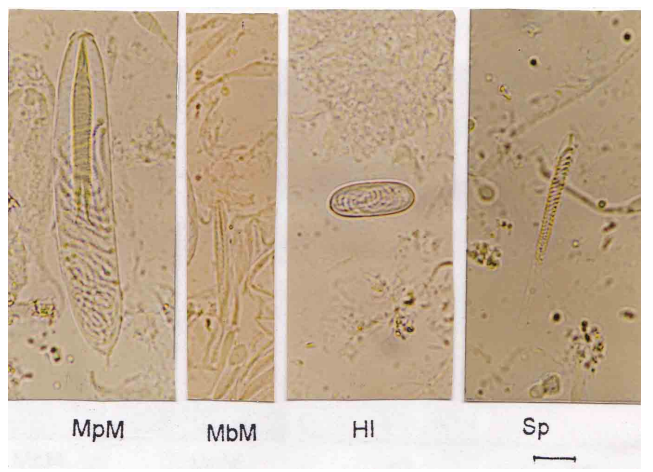

Gambar 4. Tipe dan bentuk nematosit dari karang $G$. fascicularis warna $G$ s. Skala bar $=10 \mu \mathrm{m}$.

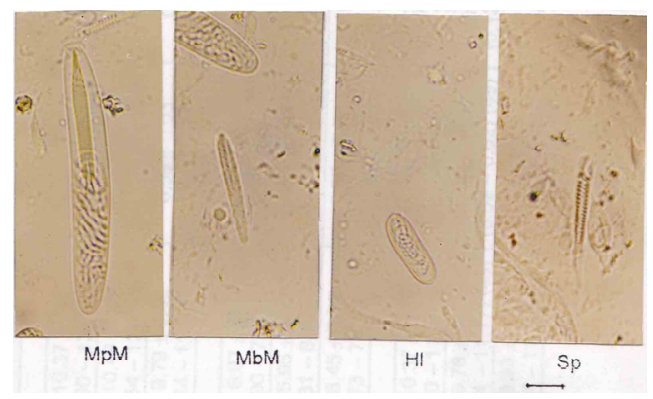

Gambar 5. Tipe dan bentuk nematosit dari karang $G$. fascicularis warna $B$. Skala bar $=10 \mu \mathrm{m}$.

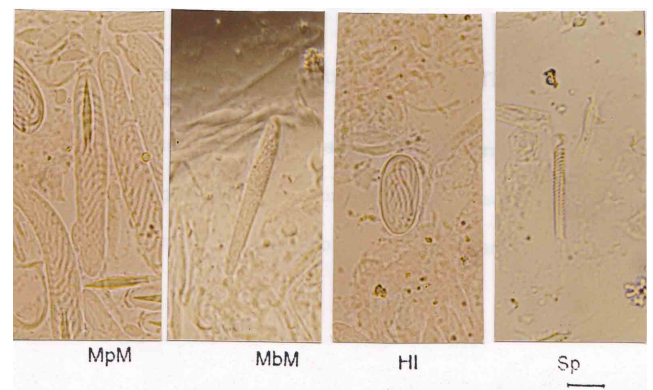

Gambar 6. Tipe dan bentuk nematosit dari karang $G$. fascicularis warna Wt. Skala bar = $10 \mu \mathrm{m}$.

hanya benang-benang saja yang bergulung-gulung (Gambar 4, 5, \& 6).

Dari hasil pengamatan dan identifikasi yang dilakukan di daerah terumbu karang di sekitar NDC lama pantai Malalayang Kota Manado, terdapat tiga macam warna karang
G. fascicularis, yaitu $G s, B$, dan $W t$, dimana ketiga warna karang ini terlihat sangat dominan di daerah pantai tersebut. Ada beberapa warna karang $G$. fascicularis yang lain yang tidak diambil dan hanya yang paling dominan saja yang diambil sebagai hewan uji.

Tiga macam warna karang G. fascicularis yang dominan ini dapat dijadikan sebagai suatu model untuk mempelajari taksonomi karang dalam spesies ini, itu artinya jika masingmasing warna karang uji ini menunjukkan spesies-spesies yang berbeda berdasarkan morfologi nematosit dan karakteristik tubuhnya, maka bisa dianggap bahwa warnawarna karang yang lain dalam spesiesspesies ini juga merupakan spesiesspesies yang berbeda. Bagaimanapun juga hal ini harus diteliti lebih lanjut untuk mendapatkan hasil penelitian yang konkrit.

$\begin{array}{lrr}\text { Hidaka (1992) menyatakan } & \text { mematosit } \\ \text { bahwa morfologi } & \text { nemato }\end{array}$ berhubungan erat dengan karakterkarakter skeleton dalam G. fascicularis. Penulis menganggap kemungkinan ada hubungan erat antara warna, karakter skeleton dan morfologi nematosit dalam karang G. fascicularis ini. Selanjutnya Paruntu dkk. (2013) melaporkan bahwa tiga spesies karang dalam genus Pocillopora, yaitu $P$. eydouxi, $P$. woodjonesi dan $P$. verrucosa dari pantai Malalayang Kota Manado mempunyai tipe-tipe nematosit yang sama, tetapi memiliki dimensi dan komposisi nematosit yang berbeda.

Hidaka \& Yamazato (1985) menyatakan bahwa warna karang Gs dan $B$ termasuk pada $G$. fascicularis yang memiliki coenosteum lunak, sedangkan warna karang $W t$ termasuk pada $G$. fascicularis yang memiliki coenosteum keras.

Tipe-tipe nematosit yang diamati pada bagian ujung jaringan tentakel normal dari tiga macam warna karang G. fascicularis ( $G s, B$, dan $W t$ ), yaitu tipe MpM, MbM, dan $\mathrm{HI}$, serta yang paling dominan adalah tipe MpM, Hasil penelitian ini adalah sesuai dengan apa 
yang dinyatakan oleh Hidaka dan Yamazato (1984). Watson \& Wood (1988) meneliti struktur dan distribusi cnida pada karang Scleractinia dan melaporkan bahwa bagian tentakel karang scleractinia memiliki tipe MpM, MbM dan $\mathrm{HI}$, dan yang dominan diantaranya adalah MbM.

Tipe dan bentuk MpM sangat jelas terlihat berbeda antara warna karang $G S$ atau $B$ dengan $W t$ dari G. fascicularis, sedangkan antara warna karang $G$ s dan $B$ adalah serupa. Hasil ini sesuai dengan yang dinyatakan oleh Hidaka (1992). MpM dari warna karang $W t$ mempunyai kapsul-kapsul yang lebih kecil dan tangkai-tangkai yang lebih pendek dibandingkan dengan kapsul-kapsul dan tangkai-tangkai yang ada pada warna $G$ s atau $B$, sedangkan bentuk kapsul dan tangkai nematosit antara warna karang $G$ s dan $B$ adalah mirip.

\section{KESIMPULAN}

Ada tiga macam warna karang $G$. fascicularis yang paling dominan terlihat di terumbu karang sekitar N.D.C. Iama pantai Malayang Kota Manado, yaitu: warna karang $G s, B$ dan Wt.

Pada bagian ujung jaringan tentakel normal dari $G$. fascicularis terdapat tipe nematosit MpM, MbM, dan HI. MpM adalah tipe nematosit yang paling dominan. Bentuk MpM ditemukan sangat berbeda antara Gs atau $B$ dengan $W t$, sedangkan $G$ s dan $B$ serupa.

Penelitian selanjutnya tentang pengukuran dimensi dan komposisi nematosit, serta perbandingannya dengan menggunakan analisis statistik, DNA dan perbedaan faktor lingkungan habitat terhadap bermacam warna karang $G$. fascicularis sangat diperlukan.

\section{DAFTAR PUSTAKA}

Hidaka, M. 1992. Use of Nematocyst Morphology for Taxonomy of Some Related Species of Scleractinia Corals. Galaxea, 11: 21-28.

Hidaka, M., Miyazaki, I. 1984. Nematocyst discharged and surface structure of the ordinary and sweeper tentacles of a Scleractinian coral Galaxea fascicularis. Galaxea, 3: 119-130.

Hidaka, M., Yamazato, K. 1984. Intraspecific in a Scleractinian coral Galaxea fascicularis: Induced Formation of Sweeper Tentacles. Coral Reefs, 3: 77-85.

Hidaka, M., Yamazato, K. 1985. Color Morphs of Galaxea fascicularis Found in the Reef Around the Sesoko Marine Science Center. Galaxea, 4: 33-35.

Paruntu, C.P., Rifai, H., Kusen, J.D. 2013. Nematosit dari Tiga Spesies Karang Scleractinia, Genus Pocillopora. Jurnal Perikanan dan Kelautan Tropis, Vol. IX-2. FPIK-UNSRAT. MANADO. Hal. 60-63.

Paruntu, C.P., Souw, N. 2014. Morfologi Nematosit dari Dua Spesies Karang Scleractinia (Seriatopora hystrix dan Seriatopora caliendrum). Jurnal LPPM Bidang Sains dan Teknologi, Volume 1 Nomor 1. UNSRAT. MANADO. Hal. 113120.

Watson and Wood. 1988. Colloquium on Terminology. In: Hessinger, D.A. and M. Lenhoff (eds). The Biology of Nematocysts. Academic Press Inc. San Diego. 